\title{
Planning for Financially Independent Retirement
}

SADJ June 2017, Vol 72 no 5 p204 - p208

L Snyman, ${ }^{1}$ S E van der Berg-Cloete, ${ }^{2}$ J G White ${ }^{3}$

\section{ABSTRACT}

Objectives: The study investigated whether dentists in South Africa are actively planning for retirement and if they are confident about being able to retire as financially independent.

Methods: An anonymous online questionnaire was used to collect data from private dental practitioners who were members of the South African Dental Association. Stata release 11 was used for descriptive statistical analysis.

Results: The majority of the respondents (71\%) were male and $42 \%$ of respondents were older than 50 years of age. It was mostly the older respondents, namely $71 \%$ of 41-50 year old respondents, $94 \%$ of $51-60$ year old respondents and $72 \%$ of respondents older than 60 years, who were actively planning for financial independence at retirement. More than half of the respondents (54.35\%) were not confident that they would be able to retire as financially independent and think they will have to postpone their retirements.

Conclusion: Retirement planning is much more complex than simply contributing to a pension, provident or retirement annuity fund. Dental schools can play an important role in equipping dentists with the necessary knowledge and skills to enable proper retirement planning, and to encourage early retirement saving and investment to ultimately ensure financially independent retirement.

Key words: Dentists, retirement, South Africa

1. Lorraine Snyman: BChD, PG Dip Dent (Clinical Dentistry), PG Dip Dent (Practice Management), PGCHE, MBL. Lecturer: Department of Dental Management Sciences, School of Dentistry, University of Pretoria.

2. Sophy Evelyn van der Berg-Cloete: $B C h D, P G$ Dip Dent (Community Dentistry), MBA. Senior Lecturer: Department of Dental Management Sciences, School of Dentistry, University of Pretoria.

3. John George White: BChD, BChD (Hons), DTE, MBA, PhD. Head of Department: Dental Management Sciences,School of Dentistry, University of Pretoria.

\section{Corresponding author}

Lorraine Snyman:

Department of Dental Management Sciences, School of Dentistry,

University of Pretoria, P.O. Box 1266, Pretoria, 0001, South Africa.

Tel: +27 123192616 , Fax: +27 123192146

E-mail: lorraine.snyman@up.ac.za

\section{INTRODUCTION}

Most individuals look forward to retirement as a time to relax and start enjoying life. Retirement can be defined as "the exit from an organisational position or career path of considerable duration, taken by individuals after middle age, and taken with the intention of reduced psychological commitment to work thereafter". In the past, age 65 was considered the mandatory retirement age, but today workers face many choices regarding the time of their retirement. ${ }^{2}$ Concern about adequate income during retirement is an important factor that influences many individuals when choosing an age to retire. Research has shown that finances are the strongest single predictor of the decision to retire and that people are more likely to leave the workforce if they can financially afford to retire than if they cannot. ${ }^{3,4}$ Other predictors for retirement include health (either mental or physical), and occupational stress. ${ }^{4}$

Retirement planning requires knowledge of tax laws, compound interest, present and future value of money and of investment strategies. It is therefore much more complex than merely contributing to a pension, provident or retirement annuity fund. ${ }^{5}$ In South Africa, it is of concern that many people are frankly apathetic towards retirement planning. The 2015 Sanlam Benchmark survey indicated that more people are using their pension fund money to pay debt when they change work positions or are being retrenched. Furthermore, only one in every four South Africans will be able to maintain their lifestyle on retirement. 6,7 These findings were further supported by Momentum and Unisa's latest index on financial wealth of South African households, which found that only $17 \%$ of households indicated that they have enough money to retire. ${ }^{8}$ According to Swart $^{9}$ less than one out of every ten individuals in South Africa is financially independent when retiring. These statistics might be indicative of a general lack of knowledge amongst individuals about what proper retirement planning involves or how to embark on such planning.

Dental practitioners in private practice have to make provision for their retirement mostly through annuity funds and other investments during their working life, while some also rely for additional financial support on the income that they will gain when selling their practices on retirement. The American Dental Association's 2010 survey on Retirement and Investment indicated that $12.7 \%$ of dentists rely on the sale of their practice for retirement income, while $62.4 \%$ rely on family retirement savings (e.g. annuities) and $4.8 \%$ rely on other sources like real estate 
and rental income..$^{10}$ However, relying on a practice sale as even a part of a retirement strategy is risky according to some experts. ${ }^{11}$

The economy is wreaking havoc on dental practice profits, and nearly two-thirds of American dentists acknowledged that they will have to postpone retirement due to the current economy. ${ }^{12}$ In contrast to this, a study among Australian dentists found that they appear overall to be well prepared for retirement and have a significant amount of wealth stored in easily accessible, high return assets which they intend to spend on financing their retirement. ${ }^{13}$ What do South African dentists say about retirement? Do they feel as satisfied as their Australian colleagues about their retirement plans? Or are they rather sharing their American colleagues' sentiment about having to postpone retirement due to financial constraints? The study aims to shed some light on the preparedness of dentists in South Africa for retirement. No previous studies on this topic could be found.

\section{AIM}

The study investigated the perceptions of South African dentists in private practice, who were members of the South African Dental Association, about their preparedness for retirement. The objectives were to determine:

- The age at which dentists plan to retire and whether that is a realistic goal.

- Whether dentists are actively planning for retirement

- Whether dentists are confident that they will be able to retire as financially comfortable.

\section{METHODS}

The study formed part of a larger study that investigated the perceptions of dentists on strategic management to ensure a viable dental practice in South Africa. ${ }^{14}$ Permission to conduct the research study was obtained from the Research and Ethics Committee of the Faculty of Health Sciences, University of Pretoria. A cover letter that explained the purpose of the study and which invited dentists in private practice to participate was sent by the South African Dental Association (SADA) to all members on SADA's electronic database. The cover letter contained the link to the online questionnaire. Those who agreed to participate were routed via a link in the letter to the self-developed questionnaire, which was hosted online at SurveyMonkey and was used to collect data for the study. Retirement planning was a subsection of the questionnaire and consisted of four questions specifically aimed to determine at what age dentists plan to retire, to assess whether the expressed age would be a realistic goal, to enquire of their situation regarding retirement planning, and to ascertain whether respondents were confident that they would be able to retire in a financially independent state. Stata Release 11 was used for data analysis, which was mainly descriptive in nature.

\section{RESULTS}

The survey was sent to 3367 members of the South African Dental Association (SADA). The SADA electronic database includes members working in the public sector, members outside the borders of South Africa, Oral Hygienists as well as Dental Therapists. The questionnaire requested feedback only from dentists in private practice. A total of 184 respondents answered the questions related to retirement planning. The majority of the

\section{Table 1: Demographic distribution of respondents}

\begin{tabular}{|c|c|c|}
\hline & $\mathrm{n}$ & $\%$ \\
\hline $\begin{array}{l}\text { Sex } \\
\text { Female } \\
\text { Male }\end{array}$ & $\begin{array}{c}54 \\
130\end{array}$ & $\begin{array}{l}29.35 \\
70.65\end{array}$ \\
\hline $\begin{array}{l}\text { Age } \\
<30 \\
31-40 \\
41-50 \\
51-60 \\
>60\end{array}$ & $\begin{array}{l}25 \\
44 \\
38 \\
48 \\
29\end{array}$ & $\begin{array}{l}13.59 \\
23.91 \\
20.65 \\
26.09 \\
15.76\end{array}$ \\
\hline $\begin{array}{l}\text { Year qualified } \\
1960-1970 \\
1971-1980 \\
1981-1990 \\
1991-2000 \\
2001-2010 \\
>2010\end{array}$ & $\begin{array}{c}3 \\
32 \\
50 \\
33 \\
58 \\
8\end{array}$ & $\begin{array}{c}1.63 \\
17.39 \\
27.17 \\
17.94 \\
31.52 \\
4.35\end{array}$ \\
\hline $\begin{array}{l}\text { Years in Practice } \\
0-5 \\
6-10 \\
11-15 \\
16-20 \\
>20\end{array}$ & $\begin{array}{l}28 \\
25 \\
23 \\
17 \\
91\end{array}$ & $\begin{array}{c}15.22 \\
13.59 \\
12.50 \\
9.24 \\
49.45\end{array}$ \\
\hline $\begin{array}{l}\text { Province } \\
\text { Eastern Cape } \\
\text { Free State } \\
\text { Gauteng } \\
\text { North-West } \\
\text { Kwazulu-Natal } \\
\text { Limpopo } \\
\text { Northern Cape } \\
\text { Mpumalanga } \\
\text { Western Cape }\end{array}$ & $\begin{array}{c}17 \\
10 \\
72 \\
4 \\
28 \\
3 \\
4 \\
13 \\
33\end{array}$ & $\begin{array}{c}9.24 \\
5.44 \\
39.13 \\
2.17 \\
15.22 \\
1.63 \\
2.17 \\
7.07 \\
17.93\end{array}$ \\
\hline $\begin{array}{l}\text { Alma Mater } \\
\text { University of Limpopo (Medunsa) } \\
\text { University of Pretoria } \\
\text { University of Stellenbosch } \\
\text { University of Western Cape } \\
\text { University of Witwatersrand } \\
\text { Other }\end{array}$ & $\begin{array}{c}7 \\
85 \\
24 \\
28 \\
31 \\
9\end{array}$ & $\begin{array}{c}3.80 \\
46.20 \\
13.04 \\
15.22 \\
16.85 \\
4.89\end{array}$ \\
\hline $\begin{array}{l}\text { Type of practice } \\
\text { Solo practice } \\
\text { Partnership } \\
\text { Other }\end{array}$ & $\begin{array}{c}108 \\
39 \\
37\end{array}$ & $\begin{array}{l}58.70 \\
21.20 \\
20.10\end{array}$ \\
\hline
\end{tabular}

respondents (70.65\%) were male and $41.85 \%$ of respondents were older than 50 years of age. Demographic details of the 184 respondents are summarised in Table 1.

$$
\begin{aligned}
& \text { - Actively planning for retirement } \\
& \text { Planning for retirement, but not seriously } \\
& \text { Currently not planning for retirement at all }
\end{aligned}
$$

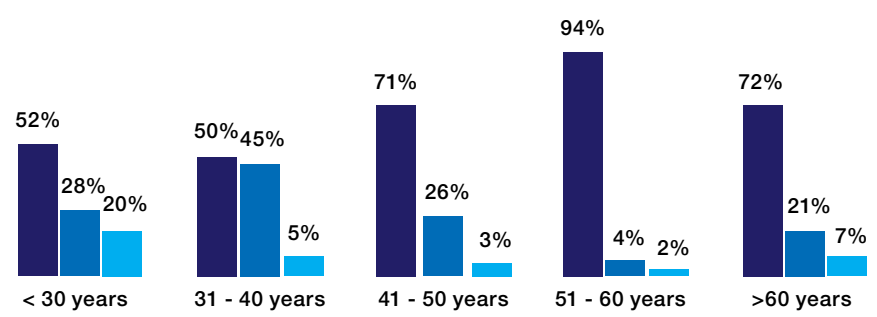

Figure 1: Retirement planning according to age 


\begin{tabular}{|c|c|c|}
\hline & $\mathrm{n}$ & $\%$ \\
\hline $\begin{array}{l}\text { Good age for retirement } \\
<55 \text { years } \\
55-59 \text { years } \\
60-64 \text { years } \\
65-69 \text { years } \\
70 \text { years and older } \\
\text { Never }\end{array}$ & $\begin{array}{l}12 \\
33 \\
35 \\
56 \\
42 \\
6\end{array}$ & $\begin{array}{r}6.52 \\
17.94 \\
19.02 \\
30.43 \\
22.83 \\
3.26\end{array}$ \\
\hline $\begin{array}{l}\text { Will selected age for retirement be a realistic goal? } \\
\text { Yes } \\
\text { No }\end{array}$ & $\begin{array}{c}108 \\
76\end{array}$ & $\begin{array}{l}58.70 \\
41.30\end{array}$ \\
\hline $\begin{array}{l}\text { Situation regarding retirement planning } \\
\text { I am actively planning for financial independence at } \\
\text { retirement } \\
\text { I am planning for retirement but not seriously } \\
\text { Currently I am not involved in financial planning for } \\
\text { retirement at all }\end{array}$ & $\begin{array}{l}128 \\
45 \\
11\end{array}$ & $\begin{array}{c}69.57 \\
24.46 \\
5.98\end{array}$ \\
\hline $\begin{array}{l}\text { Do you feel confident that you will be able to retire } \\
\text { comfortably (financially independent)? } \\
\text { Yes, I am confident } \\
\text { No, I am not confident and will have to postpone my } \\
\text { retirement }\end{array}$ & $\begin{array}{c}84 \\
100\end{array}$ & $\begin{array}{l}45.65 \\
54.35\end{array}$ \\
\hline
\end{tabular}

were in fact sent out to every member of the Association, whether in public service, or as Dental Therapist or Oral Hygienist. (Desired sample size from estimated number of private practitioners at 2760 SADA members at 95\% confidence limit would have been about 350 responses). Within those limitations, however, the outcomes of the descriptive analysis are still revealing of a trend.

From the results it is evident that those dentists who participated in this section of the overall study still value the traditional opinion about retirement age being near 65 years of age, as the majority of respondents indicated 65-69 years of age as being "good" for retirement. A large percentage (22.83\%) of respondents preferred retirement at 70 years or older. It may be assumed that as the officially recognized retirement age for South Africans is 65, this may have influenced the responses, although the reasons for the preferences were not explored. Another assumption, which was to some degree strengthened by the other results of

When asked to indicate what age respondents feel would be a good age for retirement, the majority $(30.43 \%, n=56)$ indicated that 65 to 69 years is desirable, followed by $22.83 \%(n=42)$ of respondents who indicated that 70 years or older will be appropriate (Table 2).

The majority of respondents (69.57\%) are actively planning for their retirement and only $5.98 \%$ are not involved in any financial planning for retirement (Table 2).

Twenty percent of respondents younger than 30 years of age are currently not involved in retirement planning at all, while this also applies to $7 \%$ of respondents older than 60 years (Figure 1). It was mostly the older respondents, namely $71 \%$ of $41-50$ year old respondents, $94 \%$ of $51-60$ year old respondents and $72 \%$ of respondents older than 60 years, who are actively planning towards having financial independence at retirement (Figure 1).

Results indicated that more than half of the respondents (54.35\%), however, are not confident that they will be able to retire financially independent and think they will have to postpone their retirements (Table 2).

\section{DISCUSSION}

Most people look forward to retirement as a time to start relaxing and enjoying life. Unfortunately, the harsh reality is that only a few can afford to retire financially independent and to maintain their pre-retirement lifestyle. In contrast to Australian dentists who seem to be generally well-prepared for retirement. ${ }^{13}$ American dentists are not so confident about financially independent retirement, and think they will have to postpone their retirement. ${ }^{12}$ The current study investigated the perception of dentists in South Africa on their preparedness for financially independent retirement.

The response of only 184 dentists from 3367 questionnaires is admittedly disappointing but it is to be recognised that the request to complete the Questionnaire was limited to dentists in private practice, whilst the survey documents this study, may be that financial constraints simply prevent dentists from retiring earlier, and that the majority then have no option other than to work at least to the age of 65 years, or even longer. Research has shown that most of the time people will, wisely, retire only if they can financially afford to do so. ${ }^{3,4}$ It is also a known fact that people worldwide are living longer, ${ }^{15}$ and studies postulate that individuals expecting to live longer will retire at an age later than would those expecting to die early, as they will need greater wealth to finance more years of retirement. ${ }^{16,17}$ This might also explain the intentions of many dentists to retire at an older age.

The results of this study indicate that the majority of respondents $(69,75 \%)$ are actively planning for retirement. Clearly, it is mostly the older respondents, namely $71 \%$ of 41-50 year old respondents, $94 \%$ of $51-60$ year old respondents and $72 \%$ of respondents older than 60 years, who are committed to planning for financial independence at retirement. A survey among Australian dentists aged 50 years and older enquiring about their preparedness for retirement, reported comparable findings, namely that $84 \%$ of older dentists are actively planning for financial independence in retirement, $12 \%$ were planning but not seriously, and only $4 \%$ were not involved in financial planning at all. ${ }^{13}$ The fact that $45 \%$ of respondents in this study aged 31 to 40 years and $28 \%$ of respondents younger than 30 years are not seriously planning for retirement, and that $20 \%$ of respondents younger than 30 years are not planning for retirement at all, might be a concern. Most experts agree that one should begin to plan and save for retirement as early as possible, preferably as soon as an income is being earned.18-22 The later you start to save, the less you will have when you reach retirement, and when you start saving only as you get older, you will also have to put more into retirement savings to try to make up for the years when you were earning an income but not saving towards retirement. Recognising the need for an early commitment to preparation for retirement, Dental Schools can definitely play a role in educating dental students on the importance of proper retirement planning and early retirement saving and investment. 
More than half of the respondents in this study (54.35\%) are not confident that they will be able to retire financially independent and think they will have to postpone their retirement. This finding came as no surprise, given similar findings amongst American dentists, ${ }^{12}$ and the general statistics indicating that most individuals in South Africa will not be able to retire financially independent. ${ }^{6-9}$ But if financial independent retirement seems to be such an elusive goal for most, the question must then certainly be just how much do you then actually need in order to retire with financial confidence? Unfortunately there is no easy, straightforward answer to this question, since the requisite amount of retirement funding is based on your specific needs (e.g. health care benefit expenses) and your spending habits. Furthermore, there are three variables influencing retirement capital that are unpredictable, namely: how long you will live, what inflation will be in the future, and what return you will earn on investments. ${ }^{23}$

Although it is difficult to determine an exact amount which will be needed, there are broad ranges and guidelines used by financial experts that can give you some idea of what should be enough. Popular financial guru Dave Ramsey ${ }^{24}$ advises that one should save a certain percentage of your income (typically $15 \%$ ) annually for retirement. Swart ${ }^{9}$ proposes as a broad, conservative estimate that one should have at least 10 times your annual gross salary in investment if you want to retire at age 65 and if you want to retire earlier, then at least 12 times your annual gross salary. Another calculation commonly used by financial advisors to determine retirement capital for financial independent retirement is the $4 \%$ rule, first established by William Bengen ${ }^{25} 22$ years ago. Bengen used historical returns to illustrate that with a balanced investment portfolio one can safely withdraw $4 \%$ the first year and then an inflation-adjusted amount every year for 30 years of retirement without a significant risk of running out of money. According to this rule, then, one needs enough retirement capital saved to be able to meet your annual expenses in year one of retirement by withdrawing $4 \%$ of your nest egg. To illustrate, if you need to generate from your retirement capital R50 000 per month to cover expenses in year one, you'll need to have R15 000000 saved for retirement (R15 $000000 \times 4 \%=$ R 600000 p.a. = R 50000 p.m.) To reverse the maths: to be able to withdraw 4\% in year one means having 25 times your annual spending invested for retirement. Although the $4 \%$ rule is widely used in the financial world due to its simplicity to understand and implement, it has also received much criticism over recent years ${ }^{21,26-32}$ due to certain facts such as it does not account for variable spending patterns, different tax brackets, investment costs, market volatility and different asset classes amongst other considerations.

Although only guidelines, the above numbers might be quite sobering to many readers. Unfortunately, the reality remains that most people underestimate what they will actually need for retirement, and do not save enough for financially independent retirement. The importance of early retirement saving and investment can therefore not be stressed enough. For those amongst us that have not given much thought to retirement planning, the advice will be to sit down and do it as soon as possible. Swart9 proposes three steps when planning for retirement. First, establish your retirement goals: e.g. maintaining an equal standard of living as before retirement or aiming for a $75 \%$ replacement ratio, your desired age of retirement, just saving enough to last you for your retirement or leaving behind a legacy for your loved ones. Secondly, establish an amount required to attain the set goals. This amount is determined by assessing the expenses and income during retirement. Lastly, prepare an investment portfolio within the constraints of your personal financial budget.

\section{CONCLUSION}

Retirement planning is much more complex than simply contributing to a pension, provident or retirement annuity fund, since it also requires knowledge of tax laws, compound interest, present and future time value of money and investment strategy. Financial experts also agree on the importance of starting retirement planning, saving and investment early in one's career. Statistics indicate that most individuals in South Africa will not be able to retire financially independent. The majority of respondents in this study also share this sentiment and think they will have to postpone their retirement due to financial constraints. Dental schools can play an important role in equipping dentists with the necessary knowledge and skills to enable proper retirement planning, and early retirement saving and investment to ultimately ensure financial independent retirement.

\section{LIMITATIONS}

The study reports on the responses of a relatively small sample of the private dentist population of South Africa who are members of SADA and have internet access. Whilst the data may then have limited application, the philosophy and encouragement regarding early financial planning are well supported.

\section{Acknowledgement}

We would like to acknowledge Prof PH Becker (Biostatistician, Faculty of Health Sciences, University of Pretoria) for his help with the statistical analysis of results.

Declaration: No conflict of interest declared.

\section{References}

1. Feldman DC. The decision to retire early: A review and conceptualization. Acad Manage Rev. 1994;19(2):285-311.

2. Wiatrowski WJ. Changing retirement age: ups and downs. Monthly Lab Rev. 2001;124:3.

3. Taylor MA, Shore LM. Predictors of planned retirement age: an application of Beehr's model. Psychol Aging. 1995;10(1):76.

4. Beehr TA, Glazer S, Nielson NL, Farmer SJ. Work and nonwork predictors of employees' retirement ages. J Vocat Behav. 2000;57(2):206-25.

5. Botha M, Du Preez L, Geach W, Goodall B, Rossini L, Rabenowitz P. The South African financial planning handbook. Durban: LexisNexis; 2012.

6. Van Rooyen G. Concerns about retirement apathy (Kommer oor 'aftrede-apatie'). Beeld. 2015 May 29.

7. Reddy M [Internet]. Sanlam BENCHMARK Survey: Holistic Planning Needed to Ensure Good Retirement Outcomes. Sanlam; [cited 2015 May 28]. Available from: https://www. sanlam.co.za/mediacentre/media-category/media-releases/ Sanlam\%20 BENCHMARK\%20Survey\%20\%20Holistic\%20 planning\%20needed\%20to\%20ensure\%20good\%20retirement\%20outcomes.

8. Joubert N. Households broke - and without a plan (Huishoudings platsak - en sonder ' $n$ plan). Beeld. 2015 September 28.

9. Swart N. Personal financial management: the Southern African Guide to Personal Financial Planning: Juta; 2012.

10. American Dental Association 2010 Survey on Retirement and Investment. Available from: http://www.ada.org/en/searchresults\#q=Survey\%20on\%20retirement\%20and\%20investment. Accessed May 29, 2016. 
11. Pride J, Hufford B. Ready... set... retire! Dent Econ. 2001;91(6):58-65

12. Du Molin, J [Internet]. Retirement? Dentists may have to keep working. The Wealthy Dentist; [cited 2015 June 29]. Available from: http://thewealthy dentist.com/pr/103-dental-retirement.htm.

13. Schofield D, Fletcher S, Page S, Callander E, Shrestha R. How well prepared are Australian dentists for retirement? A survey of practitioners aged 50 and above. Int Dent J. 2010;60(4):285-92

14. Snyman L, van der Berg-Cloete SE, White J. The perceptions of South African dentists on strategic management to ensure a viable dental practice. S Afr Dent J. 2016;71(1):12-8.

15. Van Rooyen G. Pension: Only $15 \%$ in SA live comfortably (Pensioen: Net 15\% in SA leef gemaklik). Beeld. 2015 January 29.

16. Van Solinge H, Henkens K. Living longer, working longer? The impact of subjective life expectancy on retirement intentions and behaviour. Eur J Public Health. 2009;20(1):47-51.

17. Hurd MD, Smith JP, Zissimopoulos JM. The effects of subjective survival on retirement and social security claiming. J Appl Econ. 2004;19(6):761-75.

18. Anderson M, Li Y, Bechhofer F, McCrone D, Stewart R. Sooner rather than later? Younger and middle-aged adults preparing for retirement. Aging Soc. 2000;20(4):445-66.

19. Long G. Planning for a financially secure retirement. Experience. 2003:13:14-7.

20. Shagrin SS. Retirement saving and financial planning: Different from a decade ago. Generations. 2002;26(2):40.

21. Pfau WD. Safe savings rates: A new approach to retirement planning over the lifecycle. J Fin Plan. 2011;24(5):42-50.

22. Rees TD. More on retirement: It is never too early to prepare.
Plastic and Reconstructive Surgery. 2005;116(2):670-1.

23. Cairns $P$ [Internet]. Do you really have enough to retire? Moneyweb [cited 2015 June 29]. Available from: http://www. moneyweb.co.za/mymoney/moneyweb-personal-finance/doyou-really-have-enough-to-retire/.

24. Ramsey D [Internet]. The truth about retirement [cited 2016 May 19]. Available from: https://www.daveramsey.com/blog/ the-truth-about-retirement/.

25. Bengen WP. Determining withdrawal rates using historical data. J Fin Plan. 1994;7(4):171-80.

26. Guyton JT. Decision rules and portfolio management for retirees: Is the 'safe'initial withdrawal rate too safe? J Fin Plan. 2004;17(10):54-62.

27. Guyton JT, Klinger WJ. Decision rules and maximum initial withdrawal rates. J Fin Plan. 2006;19(3):48-58.

28. Scott JS, Sharpe WF, Watson JG. The $4 \%$ rule-at what price? J Invest Manage. 2009;7(3):31-48.

29. Pfau WD. An international perspective on safe withdrawa rates from retirement savings: The demise of the four percent rule? J Fin Plan. 2010;23(12):51-61.

30. Finke MS, Pfau WD, Blanchett D. The four percent rule is not safe in a low-yield world. J Fin Plan. 2013;26(6):46-55.

31. Pfau WD. Ten Reasons Why the Four Percent Rule is too Simplistic. The American College Faculty Publications, Paper 366, 2014. Available from: http://digitalcommons.theamericancollege.edu/faculty/366. Accessed June 3, 2016.

32. Pfau WD, Cooper J. The yin and yang of retirement income philosophies. Challenger Limited, 2014. Available from: http:// www.republicast.com/publications /6a490775ca994e50a54c a9ac68b550c3/\#p=1\&c=0\&v=1. Accessed June 3, 2016.

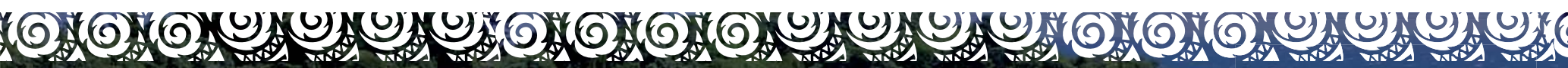
JONUS NNEW ZEALAND ANDHAVEA

\section{NEW ZEALAND PASSENGER ARRIVAL CARD}

Rated in the top ten safest countries in the world - New Zealand is the place where you can enjoy beaches, parks, award-winning wine, world-class restaurants and a range of cultures right on your doorstep - literally.

New Zealand has that perfect combination of big city and country town all rolled into one. With a great community feel, excellent schooling and a thriving economy - New Zealand really is a place that you can call home.

With 91 practices nationwide there are opportunities everywhere to enjoy the lifestyle you want, plus enjoy:

(D) Excellent salary, standard of living and work/life balance

() Lucrative earning potential in smaller towns

() Career advancement and development within the Lumino Group

1 We need talented

\begin{tabular}{llllllllll|l|l|l|l|l|l|l|l|l} 
D & E & $\mathbf{N}$ & $\mathbf{T}$ & $\mathbf{A}$ & $\mathbf{L}$ & & $\mathbf{C}$ & $\mathbf{L}$ & I & $\mathbf{N}$ & I & C & I & $\mathbf{A}$ & $\mathbf{N}$ & $\mathbf{S}$
\end{tabular} to start

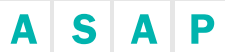

2 For further information:

\begin{tabular}{lllllllllllll|l|l|l|l|l|l|l|l|l|l} 
C & A & $\mathbf{R}$ & $\mathbf{E}$ & $\mathbf{E}$ & $\mathbf{R}$ & $\mathbf{S}$ &. & $\mathbf{L}$ & $\mathbf{U}$ & $\mathbf{M}$ & $\mathbf{I}$ & $\mathbf{N}$ & $\mathbf{O}$ &. & $\mathbf{C}$ & $\mathbf{0}$ &. & $\mathbf{N}$ & $\mathbf{Z}$
\end{tabular} 